FACULDADE DE MEDICINA DE RIBEIRÃO PRETO

\title{
O MÉDICO, A CRIANÇA COM DEFICIÊNCIA E SUA FAMÍLIA: O ENCONTRO DAS DEFICIÊNCIAS.
}

\author{
LUIZ PASQUALIN
}

Tese apresentada ao Departamento de Puericultura e Pediatria da Faculdade de Medicina de Ribeirão Preto da Universidade de São Paulo, para obtenção do grau de doutor.

ORIENTADOR: PROF. DR. FERNANDO CARLOS SOARES

RIBEIRÃO PRETO

1998 


\section{ORAÇÃO DA CRIANÇA DIFERENTE*}

Bem aventurados os que compreendem o meu estranho passo a caminhar e minhas mãos atrofiadas.

Bem aventurados os que sabem que os meus ouvidos têm que se esforçar para compreender o que ouvem.

Bem aventurados os que compreendem que ainda que os meus olhos brilhem, minha mente é lenta.

Bem aventurados os que olham e não vêem a comida que eu deixo cair fora do prato.

Bem aventurados os que, com um sorriso nos lábios, me estimulam a tentar mais uma vez.

Bem aventurados os que nunca me lembram que hoje fiz a mesma pergunta duas vezes.

Bem aventurados os que compreendem que me é difícil converter em palavras os meus pensamentos.

Bem aventurados os que me escutam, pois eu também tenho algo a dizer.

Bem aventurados os que sabem o que sente o meu coração embora não o possa expressar.

Bem aventurados os que me amam como sou, tão somente como sou e não como eles gostariam que eu fosse.

\footnotetext{
* Extraído da publicação "Informaciones para padres de niños y jovenes com necessidades especiales" Serrano, J.A.; Marrero, E.; Blas, G.C. de San - Mérida, Venezuela, 1989, apud Regen et al., 1994, p. 65-66
} 


\section{DEDICATÓRIA}

À memória de Nelson Pasqualin, meu pai, e João Augusto de Oliveira, meu sogro, perdas irreparáveis que marcaram minha existência durante o período em que buscava entendê-la por meio deste trabalho.

A forma como viveram e trabalharam me mostraram formas distintas de como o Espírito pode se realizar no trabalho humano, quando se reconhece nas coisas que faz.

\section{$\underline{\text { O FAZEDOR DE COISAS }}$}

Transformar o ferro bruto em curvas delicadas, fazer coisas úteis da inutilidade.

Mesas, cadeiras, portas, chaves, janelas, camas

e uma infinidade de coisas que servem.

Servem para a vida, vivem junto a nós o cotidiano imperceptível da existência.

Coisas concretas, formas de expressar um sentimento abstrato: Amor pelas pessoas!

Quando faltam palavras e gestos, as mãos ásperas e calejadas transformam a matéria inerte.
Fazem funcionar o que não funcionava, produzem funcionalidade, trazem comodidade... felicidade.

Coisa que os poetas e homens cultos não conseguem definir, porque está nas coisas simples.

Tão simples que só se percebe quando se perde. Percepção dolorosa e serena de quem conhece segredos tarde demais

O segredo da vida eterna do fazedor de coisas, que vence a morte porque sobrevive nas coisas que fez. 
À Marisa, companheira de todos os momentos, confirmação segura de minha existência.

Aos meus filhos: André Luís, Mariana e Lívia, que souberam compreender a atenção roubada pela gestação deste trabalho. $\mathrm{O}$ futuro deles faz parte de minhas futuras descobertas e dão sentido à minha trajetória.

À todas as crianças com deficiência,

DEDICO ESTE TRABALHO. 


\section{AGRADECIMENTOS}

Ao meu orientador, Prof. Dr. Fernando Carlos Soares, pelos quase dez anos de convivência e pela forma tranqüila e serena com que me acompanhou pelos caminhos do conhecimento. Mais que um orientador, compartilhou com meus desejos e esteve sempre presente, nas conquistas e nas derrotas. Nossos sonhos se encontraram e se tornaram realidade, que outros poderão conhecer.

Ao Prof. Dr. Marco Antônio Barbieri, que me iniciou na carreira de pesquisador, pela forma segura como me apontou os desvios de trajetória, teve papel decisivo na conclusão deste trabalho.

À Prof ${ }^{a}$. Dra. Janete Ricas, Prof ${ }^{a}$. Dra. Tárcia Regina da Silveira Dias e Prof. Dr. Antônio dos Santos Andrade, pela seriedade e competência com que analisaram meu trabalho.

À Profa ${ }^{a}$ Dra. Lígia Assumpção Amaral, pelo estímulo e cumplicidade de idéias.

À Profa. Dra. Stella Regina Taquette, parceira de pós-graduação e participante das discussões dos primeiros dados coletados, pela preocupação com a trajetória deste trabalho. 
Aos colegas de pós-graduação, Prof. Dr. Marcelo Zubaran Goldani, Prof. Dr. Gilson Maestrini Muza, Prof. Dr. César Xavier, pelo convívio e amizade incondicionais.

Aos funcionários da Biblioteca Central do Campus de Ribeirão Preto da Universidade de São Paulo, pela disposição de colaborar sempre.

Aos funcionários do Departamento de Puericultura e Pediatria da Faculdade de Medicina de Ribeirão Preto, pela boa vontade em colaborar.

À Profa. Lúcia Helena de Oliveira Pileggi, pelas correções no texto.

A todos os entrevistados, sujeitos desta pesquisa, pela forma com que me receberam e colaboraram para o enriquecimento deste trabalho.

À Fundação Coordenação de Aperfeiçoamento de Pessoal de Nível Superior (CAPES), pelo auxílio financeiro. 


\section{$\underline{\text { SUMÁRIO }}$}

RESUMO …

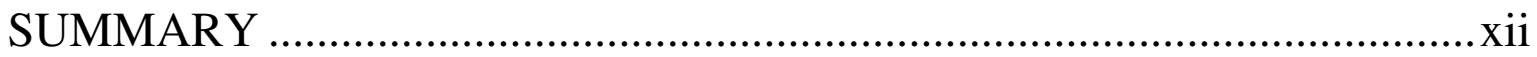

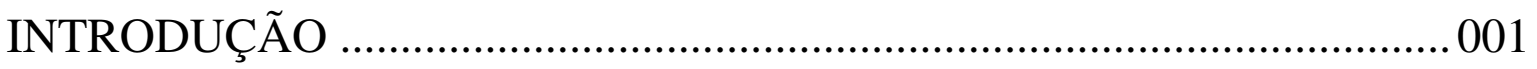

\section{CAPÍTULO I - RELAÇÃO MÉDICO-PACIENTE: UM FENÔMENO DE}

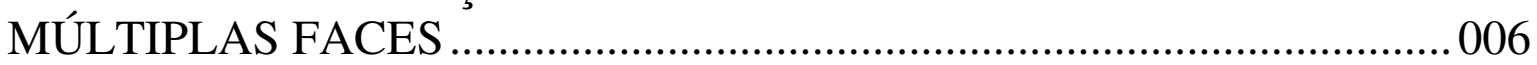

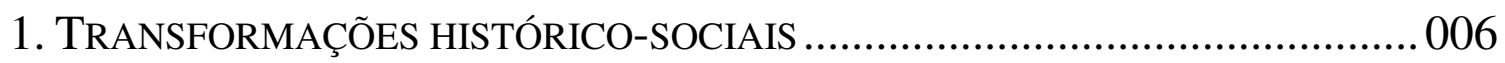

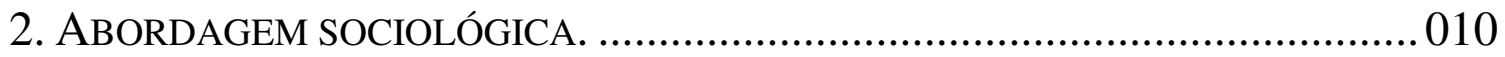

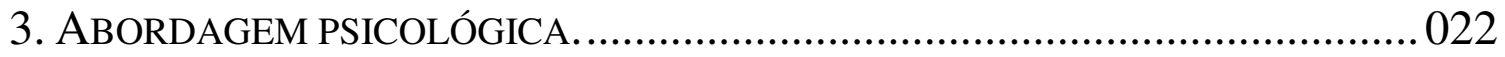

4. O "ENCONTRO” ENTRE MÉDICO E PACIENTE: UMA UTOPIA? ...................... 029

5. O ENSINO DA RELAÇÃO MÉDICO-PACIENTE. .............................................. 042

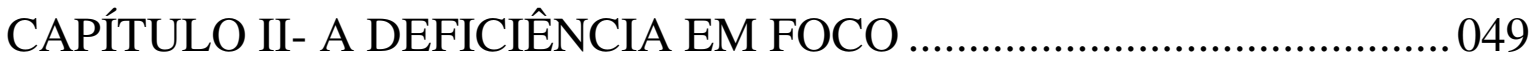

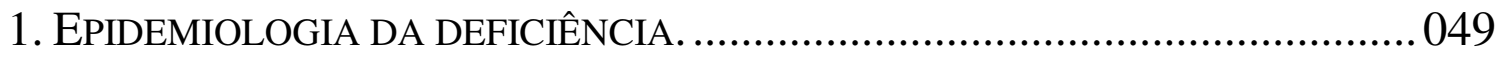

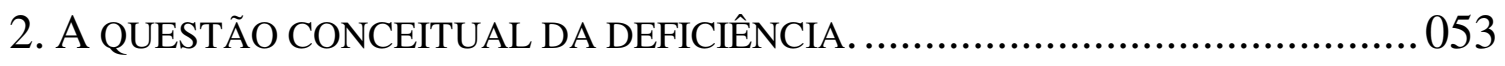

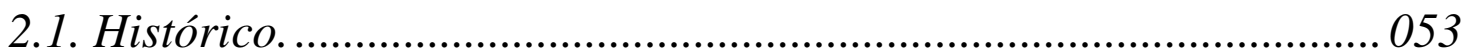

2.2. Classificação oficial das deficiências e suas conseqüências............055

2.3. A versão portuguesa da classificação oficial..................................... 056

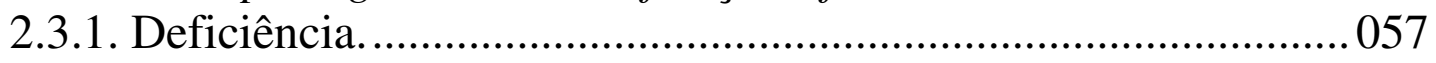

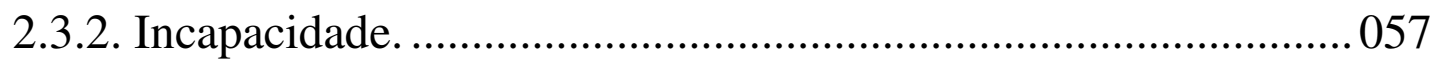

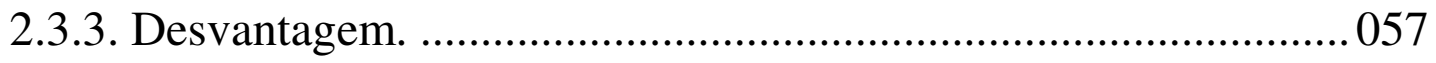

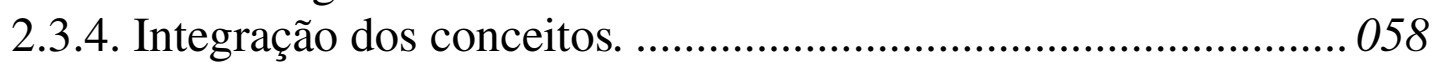

2.5. Limite entre doença e deficiência....................................................... 059

3. A SOCIEDADE E A CRIANÇA COM DEFICIÊNCIA: DA ELIMINAÇÃO AO ALVO

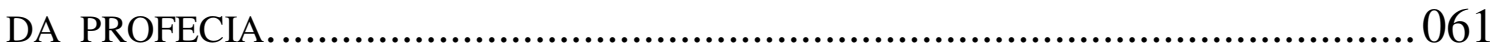

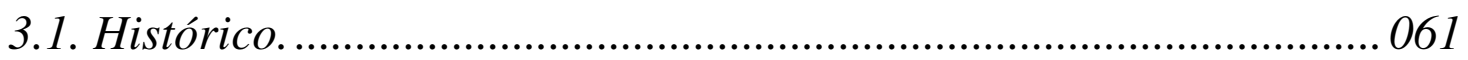

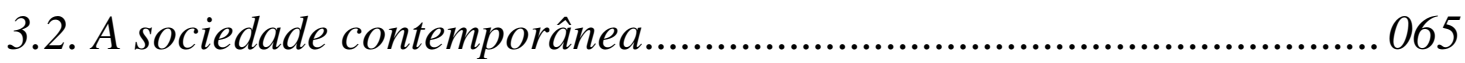

3.3. A profecia que promove sua própria realização...............................069

4. A CRIANÇA COM DEFICIÊNCIA E SUA FAMÍLIA: A IMPOSSIBILIDADE DE ESCAPAR DO DESVIO.

5. O MÉDICO E A CRIANÇA COM DEFICIÊNCIA: A ONIPOTÊNCIA QUE GERA ANSIEDADE. 


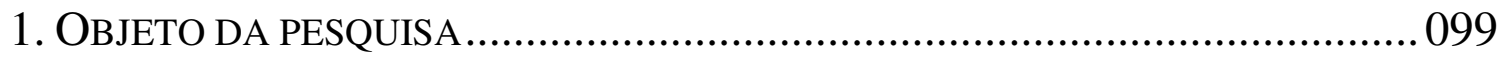

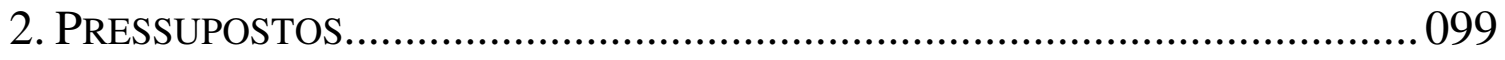

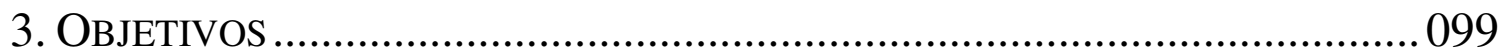

4. METODOLOGIA DE PESQUISA: DO PENSAMENTO À AÇÃO ............................. 100

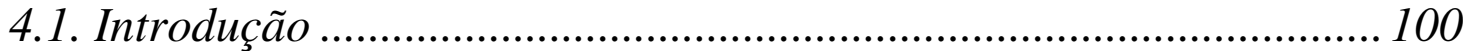

4.2. Dialética: um caminho para o conhecimento .................................. 101

5. UMA PROPOSTA DE ABORDAGEM QUALITATIVA........................................ 112

5.1. Representações sociais: o elo entre o sujeito e a sociedade............. 112

5.2. Evolução histórica do conceito de representações sociais............... 114

5.3. A contribuição da psicologia social para o conceito de

representações sociais............................................................................. 118

5.4. A contribuição do psicodrama para o conceito de representação

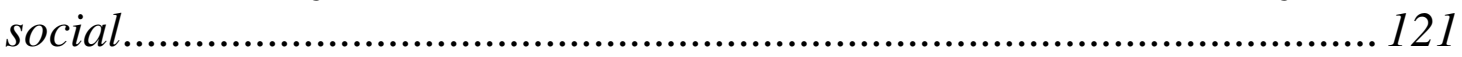

5.5. A operacionalização da pesquisa qualitativa................................. 126

5.6. Processamento da pesquisa: a leitura moreniana do processo....... 127

5.6.1. A observação participante ........................................................... 127

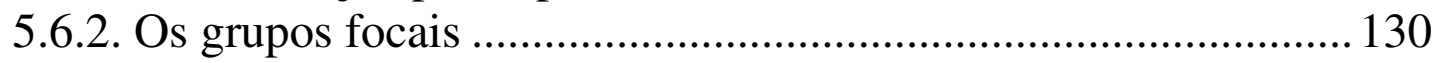

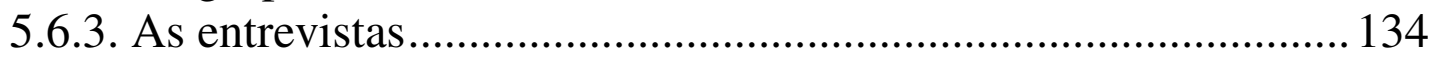

5.6.4. A entrada no campo de pesquisa e a definição da amostra ........ 136

5.6.5. Análise do material ...................................................................... 139

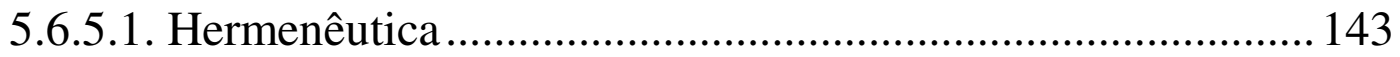

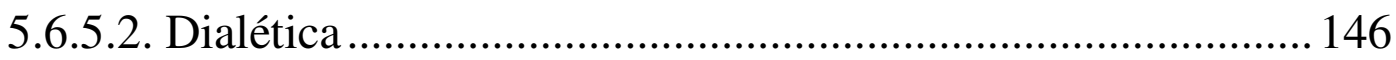

5.6.5.3. Uma proposta de análise: a "dialética moreniana"................ 147

CAPÍTULO IV - RESULTADOS E DISCUSSÃO .................................... 153

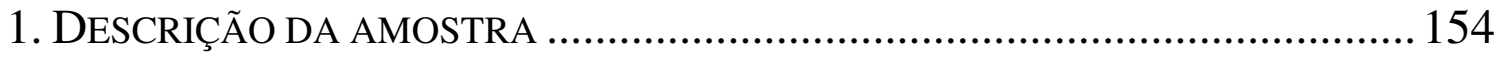

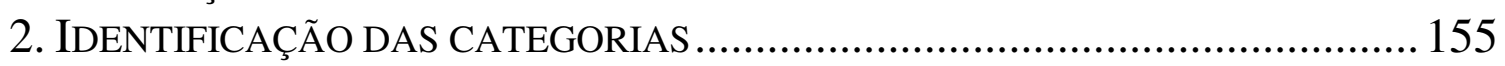

3. PERCEPÇÕES SOBRE A RELAÇÃO MÉDICO-PACIENTE................................... 156

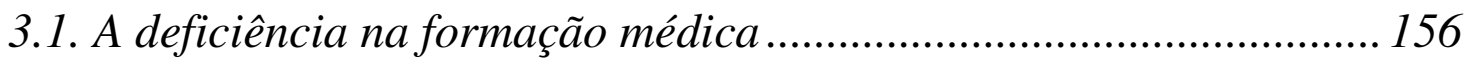

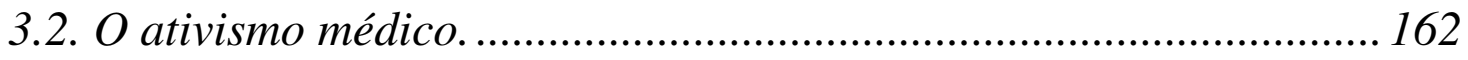

3.3. Uma relação que favorece a desigualdade...................................... 168

3.4. A prática de um conhecimento não aprendido................................ 172

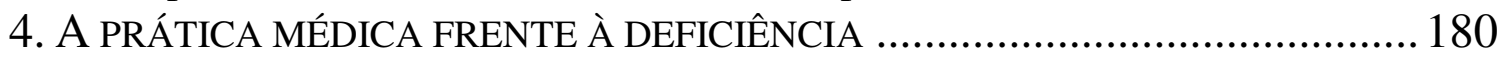

4.1. Os sentimentos despertados no médico.......................................... 180

4.2. O momento de dar a notícia aos pais............................................. 188

4.2.1. A proteção da mãe.................................................................... 188

4.2.2. Criando expectativa para proteger (proteger quem?)................. 196 


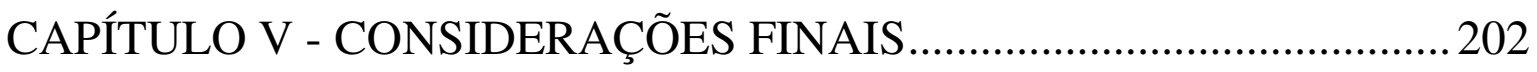

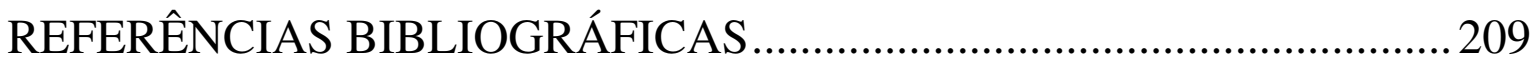

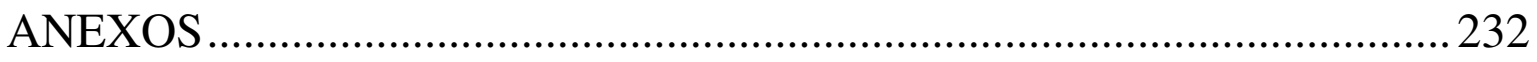

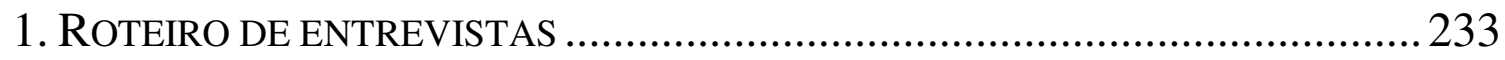

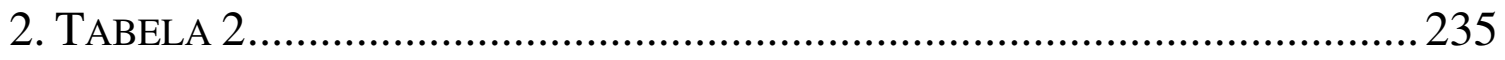

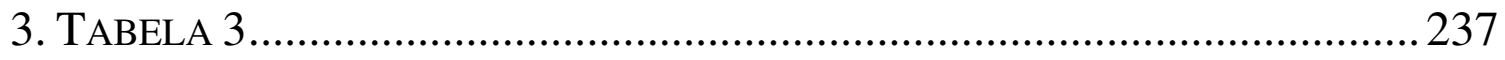

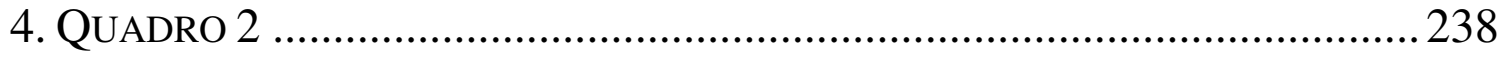

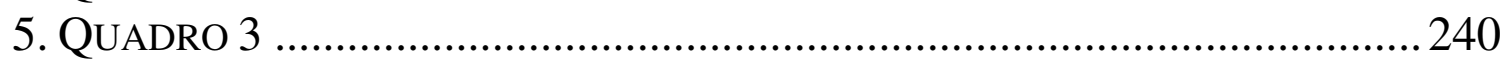

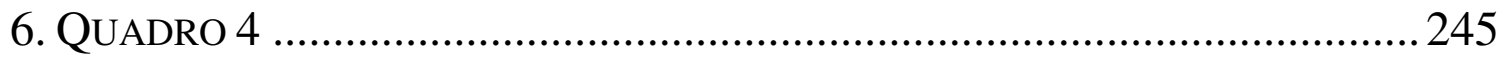




\section{$\underline{\text { RESUMO }}$}

A presente pesquisa é um estudo qualitativo sobre a relação médicopaciente em pediatria, especificamente da relação do pediatra com a criança portadora de anomalia congênita e sua família. O estudo decorre da experiência em escolas especiais, na condição de médico pediatra. O pressuposto básico desta pesquisa é que existe uma dificuldade do médico em se relacionar com estes pacientes e sua família, devido a sua formação médica "deficiente". Os objetivos da pesquisa foram: 1) identificar sentimentos e atitudes do pediatra no seu relacionamento com crianças com anomalias congênitas e seus familiares e 2) identificar as dificuldades de relacionamento do pediatra com estas famílias. A metodologia utilizada é uma "variante da pesquisa qualitativa", que trabalha o conceito de representações sociais, segundo as correntes de pensamento mais importantes na área da saúde, aliada ao método psicodramático na coleta e análise dos dados. Foram entrevistados 10 (dez) pediatras, utilizando-se um roteiro de entrevista do tipo semi-estruturada. As entrevistas foram gravadas em fita cassete e a análise dos dados evidenciou a "deficiência" da formação médica no ensino da relação médico-paciente. Além disso, emitimos a tese de que esta dificuldade está ligada com a imagem de onipotência, tanto do médico como de outros profissionais de saúde, fruto de sua formação universitária. Quanto à prática médica pôde-se identificar uma atividade intensa em número de horas por dia de trabalho, que prejudica a formação continuada formal e informal, a 
reflexão sobre esta prática e a atenção dispensada a cada paciente, caracterizando o que chamamos de "ativismo". Também pudemos perceber diferenças na relação médico paciente quanto à classe social do paciente. Foram identificados sentimentos de choque emocional, depressão e impotência nos médicos frente à deficiência, com destaque para a ansiedade no momento de falar com os pais sobre a deficiência de seus filhos. Quanto ao momento especifico de dar a notícia aos pais sobre o nascimento de um bebê com anomalia congênita, foram identificadas práticas consideradas inadequadas pela maioria dos estudiosos do assunto. Com a intenção de "proteger a mãe", quase todos os entrevistados revelaram a prática de contar a notícia primeiro ao pai, sem a presença da mãe, sedando-a logo após o parto. Outra prática identificada foi a de criar expectativa sobre a saúde do bebê para "preparar" a mãe e os familiares para receberem a notícia. Finalmente, é sugerido que a formação médica passe a discutir o relacionamento com famílias de crianças com deficiência e a criação de equipes multiprofissionais em maternidades e Unidades de Terapia Intensiva, com a função de transmitir informações aos pais e familiares, nos casos de anomalia congênita, estados graves de saúde com possibilidade de sequielas ou morte de bebês. 


\section{$\underline{\text { SUMMARY }}$}

(The doctor, the disabled child and its family: the meet of disablements.)

The present investigation is a qualitative study of the doctor-patient relationship in pediatrics, specifically of the relationship between pediatrician and children with congenital anomalies and their families. The study is based on the author's experience in special schools as a pediatrician. The basic assumption of this study is that the physician has difficulty in relating to these patients and their families due to his "disabled" medical training. The objectives of the study were: 1) to identify the feelings and attitudes of the pediatrician in his relationship with children with congenital anomalies and their relatives, and 2) to identify the difficulties experienced by the pediatrician in relating to this families. The methodology used was a "variant of qualitative research" which explores the concept of social representations according to the most important currents of thought in the health area, allied to the psychodrama method for data collection and analysis. Ten pediatricians were interviewed using a nonstructured questionnaire. The interviews were recorded on tape and data analysis demonstrated the "disablement" of medical training in terms of teaching about the doctor-patient relationship. In addition, the author proposes the thesis that this difficulty is linked to the image of omnipotence both of the doctor and of other health professionals, created by their university education. With respect to medical practice, intense activity was identified in terms of number of work 
hours per day, which impairs continuing formal and informal education, the reflection about this practice and the attention given to each patient, characterizing what we call "activism". It was also possible to perceive differences in the doctor-patient relationship in terms of the social class of the patient. Feelings of emotional shock, depression and impotence were detected in physicians facing these disablements, with emphasis on the anxiety they feel when they must talk to the parents about the disablement of their children. As to the specific time when the news should be broken to parents about the birth of a baby with a congenital anomaly, the practices identified are considered inadequate by most of those who study this subject. With the intention of "protecting the mother", almost all the doctors interviewed revealed the practice of first disclosing the news to the father without the presence of the mother, whom they submit to sedation soon after delivery. Another practice identified was to create expectations about the health of the baby in order to "prepare" the mother and the other relatives to receive the news. Finally, the author suggests that medical education should start to involve the discussion of the relationship with the families of disabled children and the creation of multiprofessional teams in maternities and in Intensive Care Units in order to transmit information to the parents and relatives in cases of congenital anomalies or of serious health conditions involving the possibility of sequels or of infant death. 